Ann. Zootech., 1980, 29, no h. s., 173-183.

\title{
Utilisation of feed protein
}

\author{
K. ROHR* and Y GEAY** \\ * Institut für Tierernährung der Bundesforschungsanstalt für Landwirtschaft, \\ Braunschweig-Völkenrode (Federal Republic of Germany) \\ ** Laboratoire de la Production de Viande, \\ Centre de Recherches de Clermont-Ferrand, I.N.R.A., \\ Theix, 63110 Beaumont (France)
}

\begin{abstract}
Animal and food characteristics, which exercise an influence on protein utilisation, are discussed in the first part of our paper.

Maintenance requirements have been related to the metabolic body weight and amount to $3.0 \mathrm{~g} \mathrm{DCP} / \mathrm{kg} \mathrm{W}^{0.75}$ resp. $3.25 \mathrm{~g}$ PDI $/ \mathrm{kg} \mathrm{W}^{0.75}$. Protein requirements for growth depend on the amount of protein deposited by the animal. Protein deposition is higher in bulls than in steers, and higher in late-maturing than in early-maturing breeds. Moreover, protein accretion has been shown to be age-dependent, The information on the efficiency of utilisation of absorbed amino acids for tissue synthesis is still insufficient. Based on the data of INRA, a value of 0.63 has been adopted for our calculations.

Amino acids absorbed from the small intestine of ruminants are supplied by undegraded food proteins and by microbial proteins synthesised in the rumen. The available data on protein degradation indicate that as much as 85 per cent and as little as 30 per cent may be degraded in the rumen. The synthesis of microbial protein is essentially governed by the energy supply and by the availability of nutrients, especially nitrogen. To simplify matters, the quantity of microbial protein has been related to the DOM intake, the relevant figure being $135 \mathrm{~g}$ microbial crude protein per $\mathrm{kg} \mathrm{DOM}$. The true digestibility of (undegraded) food protein is obtained from a regression equation. The values resulting from this equation are in the range of $60-95$ per cent. With regard to the true digestibility of microbial protein, a value of 70 per cent is adopted.

Examples of the co-ordination of protein requirements and protein supply are given in the second part of the paper. A factorial approach has been used for this purpose. Rations are formulated for two breeds (Friesian and Charolais) at the beginning and the end of the fattening period. The basic feedstuffs to be used are grass silage and maize silage ; a "cereal mixture" and an "oil meal mixture" are assumed to be available concentrates. With the grass silage diet, a forage : concentrate ratio of $60: 40$ (Friesians) resp. $40: 60$ (Charolais) was chosen. With the maize silage diets, the corresponding ratio was $80: 20$ and $60: 40$ for the two breeds. The factorial analysis shows the required crude protein content to be highest for the young animals on the grass silage diet (15.8 - 15.9 per cent CP in DM). The corresponding value for young animals on the maize silage diets is 14.5 per cent resp. 15.1 per cent for Friesian and Charolais bulls. The appropriate CP content for the heavy animals varies only little with diet and breed $(12.0-13.0$ per cent). The omission of the oil meal mixture in the second half of the fattening period leads to a deficit in rumen degradable nitrogen. In our model, this gap is filled by the addition of urea.

In our example rations, the utilisation of feed nitrogen ( $\mathrm{N}$ deposition divided by $\mathrm{N}$ intake) can be assumed to be $0.22-0.26$ at the beginning and $0.13-0.16$ at the end of the fattening period.
\end{abstract}




\section{Résumé \\ Utilisation des proteines alimentaires}

Au cours de la premiêre partie de cette étude, on a passé en revue les caractéristiques des animaux et des aliments qui exercent une influence sur l'utilisation des protéines.

Besoins nets : les besoins d'entretien sont fonction du poids métabolique et correspondent à $3 \mathrm{~g}$ de M.A.D. $/ \mathrm{kg} \mathrm{P}^{0,75}$ ou $3,25 \mathrm{~g}$ de P.D.I. $/ \mathrm{kg} \mathrm{P}^{0,75}$. Les besoins de production dépendent de la quantité de protéines déposée par l'animal. Celle-ci évolue avec l'âge et est plus élevée chez les mâles entiers que chez les castrés. Elle est également plus élevée chez les animaux tardifs que chez les précoces. La connaissance de l'efficacité d'utilisation des acides aminés absorbés pour la synthèse des tissus, reste encore insuffisante. On a adopté pour les calculs présentés dans la seconde partie de cette étude, une valeur de 0,63 d'après les résultats obtenus à l'I.N.R.A. (1978).

Digestion de l'azote dans le tube digestif : les acides aminés absorbés à travers les parois de l'intestin grêle des ruminants proviennent des protéines alimentaires non dégradées dans le rumen et des protéines microbiennes qui y sont synthétisées. De l'ensemble des résultats disponibles, il ressort que 85 p. 100 au plus, et 30 p. 100 au moins des protéines ingérées sont dégradées dans le rumen. La synthèse des protéines microbiennes est essentiellement fonction de la fourniture d'énergie et de la disponibilité de certains nutriments, azotés en particulier. Par souci de simplification, on a considéré que la quantité de protéines microbiennes synthétisées était fonction de la matière organique digestible ingérée et correspondait à $135 \mathrm{~g}$ de protéines microbiennes par $\mathrm{kg}$ de matière organique digestible. La digestibilité réelle dans l'intestin grêle de la fraction protéique d'origine alimentaire non dégradée dans le rumen a été obtenue à partir d'une équation de régression. Ses valeurs varient de 60 à 95 p. 100. Quant à la digestibilité réelle dans l'intestin grêle des protéines microbiennes, elle a été considérée égale à 70 p. 100.

Dans la seconde partie de cette étude, on a donné des exemples de satisfaction des besoins nets en protéines digestibles dans l'intestin grêle à partir du calcul des quantités provenant de l'alimentation. Dans ce but, une méthode factorielle a été utilisée. Les rations ont été calculées pour deux races de taurillons (Frisonne et Charolaise) en début et en fin de la période d'engraissement. Les fourrages de base - ensilage d'herbe et ensilage de maïs ont été complémentés par un mélange de céréales et un mélange de tourteaux. On a adopté les proportions respectives de fourrages et de concentré suivantes : 60/40 pour les Frisons et $40 / 60$ pour les Charolais recevant l'ensilage d'herbe ; 80/20 et $60 / 40$ pour les Frisons et Charolais recevant l'ensilage de maïs.

L'analyse factorielle montre que la teneur en protéines brutes de la ration doit être élevée en début d'engraissement : 15,8 et $15,9 \mathrm{p}$. 100 dans la matière sèche, respectivement pour les Frisons et les Charolais recevant l'ensilage d'herbe : 14,5 et 15,1 p. 100 pour ces animaux recevant l'ensilage de maïs. La teneur correspondante en protéines brutes pour les animaux en fin d'engraissement est plus faible et varie peu, quelle que soit la ration ou la race $(12$ - 13 p. 10). Le mélange de tourteau peut être supprimé au cours de la seconde moitié de l'engraissement, à condition de combler le déficit en azote dégradable dans le rumen par une addition d'urée.

Les exemples de rations choisies montrent que le rendement d'utilisation de l'azote ingéré ( $\mathrm{N}$ fixé/ $\mathrm{N}$ ingéré) atteint les valeurs de $0,22 \cdot 0,26$ en début d'engraissement, respectivement pour les Frisons et les Charolais et $0,13-0,16$ en fin d'engraissement.

\section{1. - Introduction}

The efficiency of utilisation of feed protein in growing animals depends on the ratio of tissue requirements to amino acid supply. In calculating the optimum ratio for ruminants one has to take into account the following aspects : a. protein requirements vary in relation to sex, breed, liveweight and liveweight gain of the respective animal ; b. at a given nitrogen intake the amino acid supply (i.e. the quantity of amino acids absorbed from the small intestine) may 
be different due to differences in the rumen degradability of feed protein and in the amount of microbial nitrogen reaching the duodenum. As with normal rations the major part of feed nitrogen is incorporated into rumen microbes, differences in the biological value are less pronounced than in monogastric animals.

Animal and food characteristics, which exercise an influence on protein utilisation, are discussed in the first part of this paper. The second part deals with the practical applications of the basic information i.e. examples are given how to meet the protein requirements of growing fattening bulls.

\section{2. - Factors influencing protein utilisation}

\section{A. - Protein requirements}

Protein requirements can be divided into two portions : maintenance requirements and requirements for growth.

Maintenance requirements comprise the inevitable endogenous $\mathrm{N}$ losses and the nitrogen loss through hair and surface cells. Estimates of endogenous urinary nitrogen for cattle above $200-250 \mathrm{~kg}$ liveweight (W) are $0.12 \mathrm{~g} / \mathrm{kg} \mathrm{W}$ W.73 $^{0 .}$ (ARC, 1965) resp. $0.12 \mathrm{~g} / \mathrm{kg} \mathrm{W}^{0.75}$ (NRC, 1976; INRA, 1978). The average loss of $\mathrm{N}$ in hair and scurf is $0.02 \mathrm{~g} / \mathrm{kg} \mathrm{W}^{0.75}$. Metabolic faecal $\mathrm{N}$ (MFN) has been related to dry matter intake (DMI), the amount given by ARC (1965) and NRC (1976) being $5 \mathrm{~g} \mathrm{MFN} / \mathrm{kg}$ DMI. This amount includes endogenous protein and undigested microbial protein. INRA (1978) differentiated faecal $\mathrm{N}$ into three fractions (dietary, microbial, endogenous) by using the following equation:

$$
\mathrm{NF}=0.143 \mathrm{INI}+0.0040 \mathrm{DOM}+0.0091 \mathrm{IDOM}
$$

in which faecal nitrogen (NF), insoluble nitrogen (INI), digestible organic matter (DOM), and indigestible organic matter (IDOM) are in $\mathrm{g} / \mathrm{kg}$ feed-DM. According to this equation, the amount of endogenous nitrogen in the faeces is $9.1 \mathrm{~g} / \mathrm{kg}$ indigestible organic matter. Estimates of maintenance requirements in terms of digestible crude protein (DCP) are 3.0 DCP $/ \mathrm{kg} \mathrm{W}^{0.75}$ (SCHulz et al., 1974; INRA, 1978). The corresponding value for PDI (amino acids truly absorbed from the small intestine), given by INRA (1978), amounts to $3.25 \mathrm{~g} / \mathrm{kg} \mathrm{W} \mathrm{W}^{\mathbf{0 . 7 5}}$.

Growth requirements vary in relation to protein deposition and are thus dependent on sex, breed, liveweight and liveweight gain. Details have been given in the review of RoBELIN and DAENICKE (1979). With regard to growing-fattening bulls of the two breeds, which will be considered in the second part of this paper, the following statements can be made : daily protein deposition in Friesians decreases from $160-180 \mathrm{~g}$ at the beginning $(200 \mathrm{~kg} \mathrm{~W})$ to $120-140 \mathrm{~g}$ at the end $(500 \mathrm{~kg} \mathrm{~W})$ of the fattening period. The values for Charolais buils are $225-245 \mathrm{~g}$ at $300 \mathrm{~kg} \mathrm{~W}$ and $195-215 \mathrm{~g}$ at $600 \mathrm{~kg} \mathrm{~W}$.

The information on the efficiency of utilisation of absorbed amino acids for tissue synthesis is still insufficient. One has to keep in mind that the actual rate of synthesis in the tissue greatly exceeds the net gain in protein deposition, and that part of the amino acids released in the process of protein turnover is not fully re-utilisable (WATERLow and StePhen, 1968). Hutton and ANNISON (1972) calculated the tissue requirements on the basis of the amino acid deposition and the conversion rates resulting from the NRC norms (1968) for swine. Some authors infused amino acids into the abomasum resp. duodenum and calculated the tissue requirements from plasma amino acid response curves (WAKELING et al., 
1970 ; Williams and Smith, 1974 ; Fenderson and Bergen, 1975). The results obtained so far are fragmentary and further research is urgently needed.

Recently proposed systems for protein evaluation differ considerably with regard to the assumed efficiency of utilisation of absorbed amino $\mathrm{N}$ for growth : the lowest figure of 0.47 is used by Burroughs et al. (1975), the highest figure of 0.75 is adopted by Roy et al. (1977) The value used by SATTER and RoFFLeR (1975) is 0.60. On the basis of experimental data in France, INRA (1978) calculated an efficiency of utilisation of absorbed protein of 0.63 . This value was rounded to 0.6 .

\section{B. $-N$ Metabolism in the alimentary tract}

Nitrogen conversions in the rumen have a profound influence on the amino acid nutrition of the animal. Amino acids absorbed from the small intestine of ruminants are supplied by undegraded food proteins and by microbial proteins synthesised in the rumen. Quantitative data on the nitrogen reaching the duodenum have only become available recently and are connected with the use of duodenal resp. abomasal cannulae. The amount of non-ammonia nitrogen (NAN, g/day) entering the duodenum could be related by JourneT and Verite, (1979) to the intake of digestible organic matter (DOM, $\mathrm{kg} /$ day) and in vitro non degradable nitrogen (non deg $\mathrm{N}, \mathrm{g} /$ day) :

$$
\mathrm{NAN}=22.62 \mathrm{DOM}+0.687 \text { non } \operatorname{deg} \mathrm{N}+4.3 ; n=58, r^{2}=0.93
$$

Reviews on protein degradation (ARMStrong, 1976 ; SMith, 1975 ; BeEver and Thomson, 1977 ; INRA, 1978) indicate that as much as 85 per cent and as little as 30 per cent may be degraded in the rumen. In the new protein evaluation systems, the variation in ruminal proteolysis is taken into account either by forming groups of feedstuffs of similar protein degradability (RoY et al., 1977) or by classifying feed proteins according to their solubility in a buffer solvent (INRA, 1978). From the work of the INRA group it appears that all the soluble nitrogen and 35 per cent of the insoluble nitrogen is degraded in the rumen. Thus, the extent of protein degradation (dg) can be calculated from solubility (S) in the following way :

$$
\mathrm{dg}=\mathrm{S}+0.35(1-\mathrm{S})=0.65 \mathrm{~S}+0.35
$$

Nevertheless, the supporting evidence for values on protein degradation is still meagre. One has to realise that in vivo the portion of undegraded feed protein is calculated by subtracting microbial nitrogen (plus endogenous $\mathrm{N}$ ) from the total amount of NAN entering the duodenum. Any error in estimating the proportion of microbial nitrogen will thus lead to a corresponding shift in the proportion of undegraded feed protein.

The synthesis of microbial protein in the rumen is essentially governed by the energy supply (ATP) and by the availability of nutrients, especially nitrogen. As ammonia is the main source for bacterial growth, non-protein nitrogen can be utilised for microbial protein synthesis in case of insufficient supply of rumen degradable protein. To simplify matters, the quantity of microbial crude protein - which contains 70 to 80 per cent amino acid N (TAmmingA, 1975)-has been related to the amount of organic matter apparently digested in the rumen or to the DOMintake. Values reported in the literature are in the range of 2-4 g microbial nitrogen/ $100 \mathrm{~g} \mathrm{OM}$ apparently digested in the rumen (ARMSTRONG, 1976). Apart from the influence of dilution rate (HARRISON et al., 1975) and roughage portion of the diet 
(COLE et al., 1976), a good deal of the variation can be attributed to methodical differences. Diaminopimelic acid (DAPA), which has been used as a marker for rumen microbes in most studies, results in a lower portion of microbial protein as compared to RNA, ${ }^{35} \mathrm{~S}$, and ${ }^{15} \mathrm{~N}$ (Table 1 ).

TABLE 1

RATIO OF MICROBIAL N: TOTAL NON-AMMONIA N (NAN) AT THE PROXIMAL DUODENUM A COMPARISON OF DIFFERENT METHODS

\begin{tabular}{|c|c|c|c|c|}
\hline Animals & Diet & Method & $\begin{array}{c}\text { Microbial } \mathrm{N} \\
\text { : NAN }\end{array}$ & Authors \\
\hline Sheep & Fishmeal + barley & $\begin{array}{l}\text { RNA } \\
35 \\
\text { S } \\
\text { DAPA }\end{array}$ & $\begin{array}{l}0.56 \\
0.54 \\
0.42\end{array}$ & $\begin{array}{c}\text { Ling and Buttery } \\
(1978)\end{array}$ \\
\hline Sheep & $\begin{array}{l}\text { Soyabean meal + } \\
\text { barley }\end{array}$ & ${ }^{\text {RNA }}{ }^{35}$ & $\begin{array}{l}0.70 \\
0.64 \\
0.47\end{array}$ & $\begin{array}{l}\text { Ling and Buttery } \\
\text { (1978) }\end{array}$ \\
\hline Sheep & Urea + barley & $\begin{array}{l}\text { RNA } \\
35 \mathrm{~S} \\
\text { DAPA }\end{array}$ & $\begin{array}{l}0.98 \\
0.92 \\
0.80\end{array}$ & $\begin{array}{l}\text { Ling and Buttery } \\
(1978\end{array}$ \\
\hline Cows & Hay + concentrates & $\begin{array}{l}\text { RNA } \\
\text { DAPA }\end{array}$ & $\begin{array}{l}0.78 \\
0.40\end{array}$ & $\begin{array}{c}\text { McAllan and Smith } \\
\text { (1974) }\end{array}$ \\
\hline Cows & $\begin{array}{l}\text { Maize silage, hay + } \\
\text { concentrates }\end{array}$ & $\begin{array}{l}15 \mathrm{~N} \\
\text { DAPA }\end{array}$ & $\begin{array}{l}0.70 \\
0.61\end{array}$ & $\begin{array}{c}\text { Allam et al. } \\
\text { (1977) }\end{array}$ \\
\hline
\end{tabular}

In the new protein evaluation systems values of between $19.5 \mathrm{~g}$ microbial $\mathrm{N} / \mathrm{kg}$ DOM (RoY et al., 1977) and $21.6 \mathrm{~g}$ microbial N/kg DOM have been adopted (INRA, 1978). At least the former underestimates microbial synthesis (BRANDT and RoHR, 1979).

Net absorption within the small intestine of amino $\mathrm{N}$ and of individual amino acids has been measured by several authors in sheep and cattle. With fresh or dried forages as a sole feed, net disappearance of amino $\mathrm{N}$ within the small intestine was in the range of 65 - 79 per cent (VAN'T KLOOSTER and Boekholt, 1972 ; Coelho Da Silva et al., 1972a and 1972b ; Armstrong and Hutton, 1975). At a given level of intake of dried forages, values were higher for chopped than for pelleted feeds ; for a given physical form values were lower the higher the intake (Coelho DA SiLva et al., 1972a and 1972b). With mixed diets fed to sheep, heifers, and cows, net absorption was in the range of 64 - 75 per cent (VAN'T KlOOSTER and BoEKHOLt, 1972 ; MCMENIMAN, 1975 ; JohnSton, 1976 ; SaVAGE, 1977).

In nearly any experiment, values for essential amino acid $\mathrm{N}$ were somewhat 
higher than those for non-essential amino acid $\mathrm{N}$. The extent to which net disappearance in the small intestine differs from true digestibility of microbial protein and undegraded feed protein depends on the influx and fate of endogenous protein, and on the extent of microbial growth in the lower part of the small intestine. With the assumption that $a$ ) the dietary $\mathrm{N}$ which is not digested in the small intestine is entirely recovered in the faeces and $b$ ) the undigested feed $N$ can be derived from equation 1, INRA (1978) calculates the true digestibility (ddp) of dietary protein in the small intestine as follows :

(3) $d d p=\frac{0.65 \mathrm{INI}-(\mathrm{NF}-0.0040 \mathrm{DOM}-0.0091 \text { IDOM })}{0.65 \mathrm{INI}}$

Values resulting from this equation are in the range of $60-95$ per cent. With regard to the true digestibility of microbial protein, INRA (1978) assumes a value of 70 per cent. This estimate coincides with the net absorption of microbial protein in experiments with purified diets (Ellis, 1974 ; MCMENIMAN, 1975 ; Elliot, 1977 ; HARRISON, 1977). In view of the results of SchWARTING and KAUFMANN (1978) on the true digestibility of microbial protein it appears to be somewhat too low.

\section{3. - Meeting the protein requirements of growing-fattening balls}

The digestible crude protein (DCP) system, which is still in common use all over the world, neglects the complex $\mathrm{N}$ - conversions in the alimentary tract. Thus, a factorial system will be used for the following calculations. As bull beef production is of outstanding importance in our countries (BERANGER, 1976 ; ROHR and DAENICKE, 1976), examples will be restricted to this category.

\section{A. - Outlines of the factorial approach}

Our factorial analysis is essentially in line with the framework set up by INRA (1978) and published by VERITE et al. (1979). The following assumptions have been made :

a. Maintenance requirements are $3.25 \mathrm{~g}$ PDI per $\mathrm{kg}$ Wo. 75 ;

b. PDI- requirements for growth are equivalent to protein deposition times 1.59 (assuming an efficiency of utilisation of 63 per cent) ;

c. Degradation of feed protein in the rumen can be derived from its solubility in a mineral buffer solvent (values taken from INRA, 1978) ;

d. The undegraded feed protein, which is truly digested in the small intestine (PDIA) is obtained from the equation :

(4) PDIA $=$ CP (1-dg) $\times$ ddp,

in which $\mathrm{CP}$ is the crude protein content of the feed, $\mathrm{dg}$ is the degradability in the rumen (Equation 2), and ddp is the true digestibility (Equation 3) ;

e. Microbial protein synthesis in the rumen is related to the intake of digestible organic matter and amounts to $135 \mathrm{~g} \mathrm{CP}(\mathrm{N} \times 6.25)$ per $\mathrm{kg} \mathrm{DOM}$;

f. The microbial protein, which is truly digested in the small intestine (PDIM), is obtained from an estimate of the microbial protein yield, the percentage 
of amino $N$ ( 80 per cent) and its true digestibility in the small intestine (70 per cent) :

$$
\text { (5) } \quad \text { PDIM }=135 \times \operatorname{DOM}(\mathrm{kg}) \times 0.80 \times 0.70 ;
$$

g. If the amount of rumen degradable protein (RDP) is insufficient for maximum bacterial growth, the deficit may be overcome by an addition of non-protein nitrogen i.e. urea (making no allowance for the recycling of $N$ into the forestomachs).

\section{B. - Animals and feedstuffs}

Rations will be formulated for two breeds at the beginning and the end of the fattening period (Friesian : $200 \mathrm{~kg}$ and $500 \mathrm{~kg} \mathrm{~W}$, Charolais : $300 \mathrm{~kg}$ and $600 \mathrm{~kg} \mathrm{~W}$ ).

The basic feedstuffs to be used are grass silage (early flowering) and maize silage (dough stage). A "cereal mixture" (50 per cent oats, 30 per cent barley, 20 per cent tapioca) and an "oil meal mixture" ( 70 per cent soyabean meal, 30 per cent rapeseed meal) are assumed to be the available concentrates. The characteristics of these feeds are given in Table 2.

TASLE 2

CHARACTERISTICS OF SILAGES AND CONCENTRATES (VALUES PER kg DM)

\begin{tabular}{l|c|c|c|c|c|c|c|c}
\hline Feedstuff & $\begin{array}{c}\text { DOM } \\
(\mathrm{g})\end{array}$ & $\begin{array}{c}\mathrm{CP} \\
(\mathrm{g})\end{array}$ & $\begin{array}{c}\text { DCP } \\
(\mathrm{g})\end{array}$ & $\begin{array}{c}\text { RDP } \\
(\mathrm{g})\end{array}$ & $\begin{array}{c}\text { PDIA } \\
(\mathrm{g})\end{array}$ & SE & $\mathrm{UFV}^{*}$ & $\begin{array}{c}\text { ME } \\
(\mathrm{MJ})\end{array}$ \\
\hline $\begin{array}{l}\text { Grass } \\
\text { silage }\end{array}$ & 594 & 129 & 83 & 97 & 21 & 520 & 0.69 & 9.20 \\
$\begin{array}{l}\text { Maize } \\
\text { silage }\end{array}$ & 665 & 86 & 46 & 60 & 19 & 620 & 0.78 & 10.13 \\
$\begin{array}{l}\text { Cereal } \\
\text { mixture }\end{array}$ & 778 & 101 & 77 & 62 & 37 & 779 & 1.05 & 12.43 \\
$\begin{array}{l}\text { Oil meal } \\
\text { mixture }\end{array}$ & 802 & 496 & 447 & 274 & 198 & 772 & 1.09 & 13.05 \\
\hline
\end{tabular}

${ }^{*}$ UFV = net energy unit for maintenance and meat production, equivalent to $1 \mathrm{~kg}$ of standard barley

\section{C. - Example rations}

a) Diets based on grass silage

As food intake capacity is a limiting factor when feeding medium quality grass silage, high daily gains can only be realised with a high proportion of concentrates in the diet. According to our experiences, for Friesian bulls a forage : concentrate ratio of $60: 40$ (on a DM basis) can be assumed. Because of the higher growth potential and a relatively lower feed intake capacity (GEAY, 1976), the forage : concentrate ratio for Charolais bulls should be about $40: 60$. 
Details on the adjustement of protein resp. nitrogen intake to the animals' requirements are given in Table 3.

As the amount of PDIM is relatively small at the beginning of the fattening period, a large proportion of total PDI (47 per cent) must be supplied as PDIA. This is achieved by feeding a certain quantity of the oil meal mixture $(0.47 \mathrm{~kg}$ resp. $0.70 \mathrm{~kg}$ for Friesians and Charolais). The amount of rumen degradable

TABLE 3

MEETING THE PROTEIN REQUIREMENTS OF FRIESIAN AND CHAROLAIS BULLS (BASIC FEED : GRASS SILAGE)

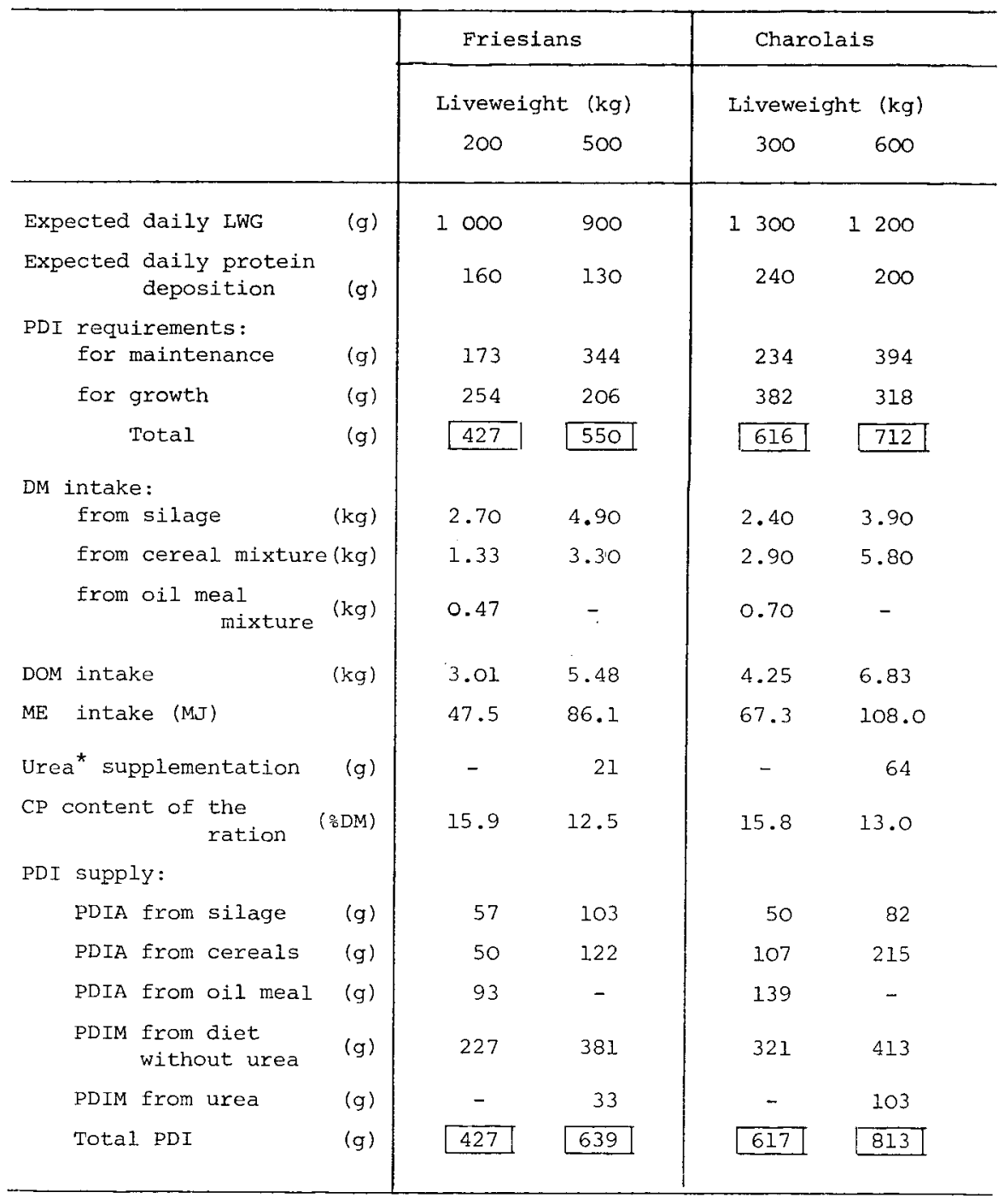

* $N$ content in urea: $46 \%$ 
nitrogen exceeds the requirements of the rumen microbes. Feed protein utilisation ( $\mathrm{N}$ deposition : $\mathrm{N}$ intake) is 0.22 for Friesians and 0.25 for Charolais bulls.

The PDI supply at the end of the fattening period is equal to or in excess of the animals' requirements, although the ration consists of grass silage and low-protein cereals only. Urea has to be added in order to overcome the deficit

TABLE 4

MEETING THE PROTEIN REQUIREMENTS OF FRIESIAN AND CHAROLAIS BULLS (BASIC FEED : MAIZE SILAGE)

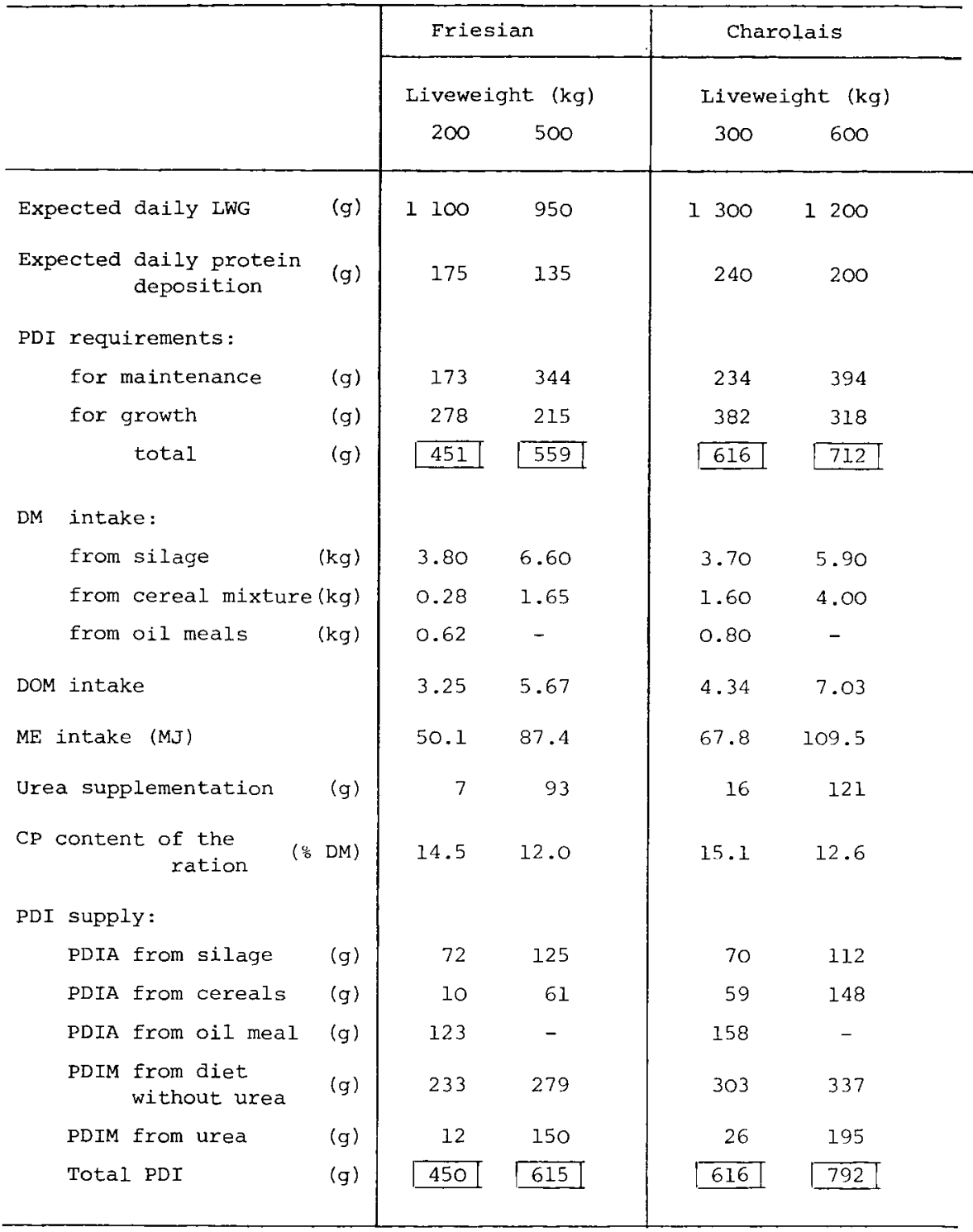


in rumen degradable nitrogen i.e. to allow maximum microbial growth. Feed $\mathrm{N}$ utilisation is 0.13 and 0.16 for Friesian and Charolais bulls respectively.

\section{b) Diets based on maize silage}

As the net energy content of maize silage is substantially higher than that of grass silage, less concentrates are necessary to achieve high daily gains. Forage : concentrate ratios of $80: 20$ (for Friesians) and $60: 40$ (for Charolais) are chosen in our examples.

The co-ordination of protein requirements and protein supply is made in Table 4. In comparison to the grass silage diets, a greater quantity of high-protein oil meal mixture is necessary for the young animals. A deficit in rumen degradable nitrogen - already noticeable at an early stage - becomes very pronounced at the end of the fattening period when the supplement only consists of cereals. Under these conditions the addition of urea - as a source of rumen degradable nitrogen - will not only secure microbial growth but will also prevent a decrease in digestibility and feed intake. The efficiency of utilisation of feed nitrogen at the beginning of the fattening period is 0.26 for both breeds. Values for the heavy animals are 0.13 (Friesians) and 0.16 (Charolais).

\section{References}

Allam S.M., Brandt, M., Daenicke R., Lebzien P., Rohr K., Schulz E., 1977. Jahresberichte der FAL 1977, G 64 - G 65.

ARC, 1965. Nutrient Requirements of Farm Livestock, No. 2. Ruminants, London.

ARmSTRong D.G., 1976. Übersichten zur Tierernährung, 4, 1-24

Armstrong D.G., Hutton K., 1975. In : McDonald I.W. and Warner A.C.I. (eds) Digestion and Metabol, in the Ruminant, 432-447. Univ. of New England Publishing Unit, Armidale.

Beever D.E., Thomson D.J., 1977. In : Haresign W. and Lewis D. (eds) Recent Advances in Animal Nutrition - 1977, 66-82.

Beranger C., 1976. In : TAYLER J.C. and Wilkinson J.M. (eds) Improving the Nutritional Efficiency of Beef production, 49-55. ECSC, EEC, EAEC, Luxembourg.

BrandT M., RoHr K., 1979. Z. Tierphysiol., Tierernährg., Futtermittelkde., 42, 25.

Burroughs W., Nelson D.K., Mertens D.R., 1975. J. Anim. Sci., 41, 933-944.

Cole N.A., Johnson R.R., Owens F.N., Males J.R., 1976. J. Anim. Sci., 43, $497-503$.

Coelho da Silva J.F., Seeley R.C., Thomson D.J., Bfever D.E., Armstrong D.G., $1972 a$. Br. J. Nutr., 28, 43-61.

Coelho da Silva J.F., Seeley R.C., Beever D.E., Prescott J.H.D., Armstrong D.G., 1972b. Br. J. Nutr., 28, 357-371.

Elliotr R., 1977. Ph. D. Thesis, University of Newcastle upon Tyne.

Ellis N., 1974. Ph. D. Thesis, University of Newcastle upon Tyne.

Fenderson C.C., Bergen W.G., 1975. J. Anim. Sci., 41, 1759-1766.

GEAY Y., 1976. In : TAYLER J.C., WILKINSON J.M. (eds). Improving the Nutritional Efficiency of Beef Production, 333-347. ESCE, EEC, EAEC, Luxembourg.

HARRISON D.G., 1977. M. Sc. Thesis, University of Newcastle upon Tyne.

Harrison D.G, Beever D.E., Thomson D.J., Osbourne D.F., 1975. J. agric, sci., 85, 93-1.

Hutton K., Annison E.F., 1972. Proc. Nutr. Soc., 31, 151-158.

INRA, 1978. L'Alimentation des Ruminants. INRA Publications, Versailles.

Johnson I.L., 1976. Ph. D. Thesis, University of Newcastle upon Tyne.

Journet M., Verite R., 1979. Ann. Rech. Vet., 10, 303-306.

Ling J.R., ButTERY P.J., 1978. Br. J. Nutr., 39, 165-179.

McMeniman N.P., 1975. Ph. D. Thesis, University of Newcastle upon Tyne.

McAllen A.B., Smith R.H. 1974. Proc. Nutr. Soc., 33, 41A-42A. 
NRC, 1968. Nutrient Requirements of Swine, 6th ed.

NRC, 1976. Nutrient Requirements of Beef Cattle, 5th ed.

Robelin J., Daenicke R., $1979 . \quad$ This seminar.

Rohr K., Daenicke R., 1976. In : TAYler J.C. and Wilkinson J.M. (eds) Improving the Nutritional Efficiency of Beef Production, 56-65. ECSC, EEC, EAEC, Luxembourg.

Roy J.H.B., Balch C.C., Miller E.L., Ørskov E.R., SMith R.H., 1977. Proc. 2nd Intern. Symp. Protein Metabolism and Nutrition, 126-129. Centre for Agricultural Publishing and Documentation, Wageningen.

Satter L.D., Roffier R.E., $1975 . \quad J$. Dairy Sci., 58, 1219-1237.

SAVAGE G.P., 1977 . Ph. D. Thesis, University of Newcastle upon Tyne.

Schulz E., Oslage H.J., Daenicke R., 1974. Fortschr. Tierphysiol. Tierernährg., Nr. 4.

Schwarting, Kaufmann W., 1978. Z. Tïerphysiol., Tierernährg., Futtermittelkde., 40, 6-18.

Smith R.H., 1975. In : MCDonald I.W. and Warner A.C.I. (eds). Digestion and Metabolism in the Ruminant, 399-415. Univer. of New England Publishing Unit, Armidale.

Tamminga S., 1975. Z. Tierphysiol. Tierernährg. Futtermittelkde., 35, 337-346.

Van't Klooster A.T., Boekholt H.A., 1972. Neth. J. agric. Sci., 20, 272-284.

Verite R., Journet M., Jarrige R., 1979. Livest. Prod. Sci., 6, 349-367.

Wakling A.E., Levis D., Annison E.F., 1970. Proc. Nutr. Soc., 29, 60A-61A.

Waterlow J.C., StePhen J.M.L., 1968. Clin. Sci., 35, 287-305.

Williams A.P., Smith R.H., 1974. Br. J. Nutr., 32, 421-433. 


\section{Discussion}

\section{Chair : A. NeIMANN-SøRENSEN (Denmark)}

A.J.H. VAN Es (The Netherlands). - In both systems I think there is a lot of variation with regard to the assumptions made. I wondered if there have been some computations with regard to the sensitivity of 10 per cent change, as we saw in Sir Kenneth's model. What is the sensitivity of the various assumptions ?

A. Neimann-S $\phi$ Rensen. - That is a very good question. Who would like to answer it, or try to elucidate it ? Have any model calculations been done ?

J.H.B. RoY $(U K)$. - Not to my knowledge.

Sir Kenneth Blaxter (UK). - Didn't you do this ? I thought we looked at this once.

J.H.B. Roy. - If we did I cannot remember the results, off hand. point ?

A.J.H. VAN Es. - Let's put the question in a simpler way. What is the weakest

J.H.B. Roy. - The degradability is the weakest point.

A.J.H. Van Es. - It is not the production of microbial protein ? I think.

J..H.B. Roy. - No. Degradability is first and microbial protein production second,

H. BICKel (Switzerland). - I wonder a bit about the constant value of the microbial protein synthesis per $\mathrm{kg}$ organic matter intake, because there is quite a big difference between the INRA assumption and yours. Professor Landis at our Institute made a study of the calculations, as in the INRA book, for dividing up the faecal nitrogen into different compartments. He has the impression that microbial synthesis per $\mathrm{kg}$ digestible organic matter is different for high roughage rations than for high concentrate rations. We do not have the figures, but it seems that the microbial synthesis is more than when you give more concentrates - that is per $\mathrm{kg}$ digested organic matter.

J.H.B. Roy. - I think there is no doubt that, in the future, there will be multiple regression equations relating microbial yield to a number of factors. The point is that when we were producing this model, nearly all the evidence was from sheep ; the amount from cattle was very small indeed. There was not sufficient evidence to produce a model including any of these other factors. In the long term, prediction has got to be improved by bringing in other variables, but we do not know what they are at the present time.

H. BICKEL. - Professor Landis' equations were also derived from sheep data.

K. RoHR (Federal Republic of Germany). - We do not agree with the view that the degradability of protein, in every case, is more important than the efficiency of microbial growth. There are new figures emerging now which show considerable deviation. For instance, what we have been doing during the last four years, using $\mathrm{N}^{15}$ with dairy cows, shows a figure of $150 \mathrm{~g}$ of microbial crude protein per kg digestible organic matter, which is a lot higher. As you made these calculations by subtracting the amount of microbial protein from the total non-ammonia nitrogen in the duodenum, in this case the breakdown of the degradability of feed protein would lose some of its importance, because the breakdown of the feed protein would be higher than is assumed so far.

J..H.B. Roy. - All I would like to add is that, on these degradability effects, we have the effect of inaccuracies in the microbial yield on degradability but, in the long term, it is the fact that you have a wrong degradability that is the important factor. If the optimum degradability is 0.70 and your ration is 0.80 degradable, and let us say that at 0.70 your concentration of crude protein is 12 per cent in the dry matter, or $120 \mathrm{~g} / \mathrm{kg}$, then at a 
degradability of 0.8 the crude protein in the ration goes up by $40 \mathrm{~g} / \mathrm{kg}$ - from 12 per cent up to 16 per cent - and that is a colossal jump. I do not know whether it is due to the microbial effect on degradability, but it is the degradability factor that is the most important.

Sir Kenneth Blaxter. - I am getting more and more concerned about how we can test the validity of the various, and much more complex, models that we are making of animal metabolism. If you take Dr. Roy's presentation, he showed us a relationship in which there was a whole series of points in which you have the total protein intake, and those generally agree. This, however, is not the test of that system ; the test of this system has got to be one in which you distinguish the UDP from the RDP. There are very few of these in existence at the moment. It is this critical testing of the highly complex models which we are now building, of the energy/protein and other aspects of metabolism, which is extremely important. Here I get even more worried because of the fact that our feeding trials are not sufficiently accurate ; that a variation in rate of growth (measured over, say, 100 days or 200 days) of a very considerable magnitude could arise simply because of the inaccuracy and problems of weighing the animal. I have certainly noticed this when trying to account for the individual variation between animals, in terms of the way in which they utilise feed, according to the little model that I was dealing with. These problems of the accuracy of doing our experiments, in order to test these very sophisticated models, is something which I think we might profitably discuss. Possibly Dr. Oslage will discuss this on the last days ; I think the question of how we test is becoming very critical.

A. NeImann-SøRensen. - I think it is very important and $I$ am sure there are many people here who would be interested in contributing to the establishment of some principles along which such testing can be done. We need this material.

G. Alderman (UK). - May I contribute on this question of how one might test and, equally, bring in some comments on degradability. This means changing gear from the re-entrant cannula approach to the Orskov dacron bag. Let me make it very clear that we are not necessarily saying that this is measuring degradability as defined by the ARC model. It is easy to define degradability - it is that proportion which is degraded to ammonia in the rumen ; the problem is to measure it. However, we have found the Ørskov dacron bag technique, with modifications which we have picked up from our Unilever colleagues at Colworth House, to be very reproducible between animals and between occasions. So, the smooth curves on the graph are a good fit to the means of four points. This work has been done by one of my staff using facilities made available to us at the Grassland Research Institute. The reason I bring it up is merely to comment on the French approach of trying to estimate degradability from solubility measurements - and then saying that what is not soluble is 65 per cent degraded. Now, with the dacron bag technique, your control is, in fact, water washed, so water solubility is the intercept on the y axis of the graph (degradability). We have not used a buffer but $I$ do not think that would make very much difference. Clearly there is an asymptote to each of the curves, and it is not always 100 per cent degradability. You will see that we have a hay here which is going to be on test at one of our Experimental Husbandry Farms, with dairy cows. If you fit the Orskov model, the asymptote is 85 per cent degradability. There is also the question of retention time and there are many paths from zero time to 48 hours retention. The Orskov mathematical model describes some of these curves but it certainly would not describe herringmeal, which is a straight line. Herringmeal has quite a proportion of stickwater which is soluble the moment you put it in the water, but it tells you nothing about the eventual degradability. By this technique, groundnut, soyabean, wheat and cereals all have low solubilities but high degradabilities. We also had one sample, a low protein hay with a high water soluble nitrogen content, which went in the reverse direction, i.e. it had a negative degradability for some hours.

It seems to me that the dacron bag technique is describing the nature of nitrogen and protein in feeds in a way which we find quite interesting. What we are trying to do, rightly or wrongly - because to do nothing is really unacceptable, when you bear in mind the stature that the ARC has in the UK - we shall be doing feeding trials using the model to pick out the areas where we should find big differences. For dairy cows, for example, the model would suggest that if you can get a low degradability diet, exactly matched, then very low protein diets should work for high milk yields. So we are deliberately testing the model, and merely using the dacron bag technique to describe the feeds that are being put on test. Whether we can make something out of it, I don't know, but that is how we are proposing to do it. At the moment, what we plan is tests of low protein diets, high protein 
diets, low degradabilities and high degradabilities. There are 4 treatments ; only 2 of them should be right, the other 2 should prove to be either non-significant or produce a depression in milk yield. We are hopeful we might get something out of it, but there are many inaccuracies in trials such as these.

A.J.H. VAN Es. - To interpret these results correctly I think you have to know the retention time in the rumen, in the actual rumen. Otherwise it is very difficult to interpret, isn't it ?

G. Alderman. - Exactly so ! That is why, if you have the curve, you can pick off an appropriate retention time. Dr. Orskov is currently working on a technique to measure the retention time of particular foods, in parallel with the dacron bag work. It is not easy but at least, in terms of the food being used, its particle size, its method of preparation, there is a lot of information already available to nutritionists about retention times.

Sir Kenneth BLaXter. - I would like to say a little about what Orskov is doing at the Rowett Institute. First of all, the shapes of some of these curves are quite interesting, and the way in which he is describing the curves, with Mr. McDonald the mathematician, is as a single limiting exponential relationship for the disappearance of nitrogen from the dacron bag. Some have a positive intercept, which is the stickwater from fishmeals and so on. Using the same feedingstuff which he is testing, treated with chromic oxide or chromium, he is in addition measuring rate of disappearance in relation to the type of diet which is being fed. The half-times of disappearance of feeds from the rumen vary quite considerably, with small amounts of ground diets where you have rather slow disappearance, with other types of diet, very fast - a range from 3 up to 14 or 15 hours in terms of a half-time of retention. This makes absolute nonsence of the solubility curves and of the disappearance curves, because it is the product of the two. In the paper by McDonald and Orskov, in the Journal of Agricultural Science published this year (vol. 92, p. 499-503), you will find a solution to that particular problem, which indicates the very wide range in which overall degradability, in terms of contributions made to fermentation, can take place - it is a very pretty piece of work.

R. JARRIGE (France). - We agree that new systems, either the ARC system or the INRA system, have a lot of parameters which are not well defined. As far as degradability is concerned, there is a misunderstanding about our system. We have used solubility to find a general equation from the data in the literature and our own. From the equation we have retained the efficiency of the protein production from DOM*. But in our tables, the values used for the degradability of most of the feeds have been derived from large "in vitro" incubations. However, sometimes for some unimportant feedstuffs, we had no incubation and we used solubility. Solubility itself is not a satisfactory method, but if you correct for large "in vitro" incubations you then have the value for each food which is shown in our table. One of our objectives was to have an additive system used like the DCP system. We know that the value for many things is probably provisional, or could be improved. But when we used these values on the preceding feeding trials, we tested the system. We show that these PDI values allowed us to explain differences in the response of animal. The high yielding dairy cow is more responsive than our growing and fattening animal and most of the improvements are to be expected from work on high yielding dairy cows. I agree with Sir Kenneth as regards the interpretation of the liveweight gain.

G. Alderman. - May I ask a supplementary question to that ? Is this "in vitro" technique of yours published ? Or could you make it available for scrutiny while we are here ? The technique intrigues me greatly.

\section{R. JARRIGE. - Yes, and you could probably see it in operation during the visit.}

K. RoHr. - I would just like to stress the point that Dr. Jarrige made, that if we are using digestible crude protein, the errors are much higher in dairy cows than in fattening animals. When you think of all the experiments made all over Europe, in order to establish the requirements in digestible crude protein, there is an astonishing agreement among all these experiments with a variety of diets. Therefore, from the practical point of view, it is much more important for dairy cows than for fattening animals.

$\left.{ }^{*}\right)$ Digestible organic matter. 